\title{
Description of the technique of bone marrow harvesting in the coxal tuberosity for isolation and culture of mesenchymal stem cells of buffaloes (Bubalus bubalis)
}

\author{
Carolina Nogueira de Moraes*, Amanda Jerônimo Listoni, Leandro Maia, \\ Carla Martins de Queiroz, Flavia Caroline Destro, Eunice Oba, \\ Fernanda da Cruz Landim-Alvarenga
}

Department of Animal Reproduction and Veterinary Radiology, São Paulo State University, Botucatu, Brazil;

*Corresponding Author: carolnmoraes@hotmail.com

Received 14 November 2013; revised 5 December 2013; accepted 12 December 2013

Copyright (C 2014 Carolina Nogueira de Moraes et al. This is an open access article distributed under the Creative Commons Attribution License, which permits unrestricted use, distribution, and reproduction in any medium, provided the original work is properly cited. In accordance of the Creative Commons Attribution License all Copyrights (C) 2014 are reserved for SCIRP and the owner of the intellectual property Carolina Nogueira de Moraes et al. All Copyright @ 2014 are guarded by law and by SCIRP as a guardian.

\section{ABSTRACT}

Several studies with mesenchymal stem cells (MSCs) have been developed in many species because of its ability to differentiate into other mesoderm lineages, capacity of self-regeneration, low immunogenicity, paracrine, anti-inflammatory, immunomodulatory and antiapoptotic effects which make them a promissory source to be used in therapeutic strategies. The aim of this study is to report the technique of harvest of bone marrow (BM) in the coxal tuberosity (CT) of buffaloes and its processing and cultivation. For this, after anesthetic block from the region corresponding to the $C T$, bone marrow harvesting was performed with a myelogram's needle. The samples collected showed plastic adherence with 96 hours and took approximately 32 days to reach $80 \%$ confluence. And then differentiation into adipogenic and osteogenic lineages was performed. Samples showed morphological changes during differentiation protocol, but not all presented production of extracellular deposits of calcium or intracellular fat droplets. The anatomical site tested showed to be an alternative site of harvest of BM once provided with the appropriate isolation and culture of the mononuclear fraction. Moreover, the procedure was performed without difficulty and with great security. Based on this, it can be concluded that CT is an excellent anatomical site for isolation and culture of MSCs and the proposed technique is viable and feasible to be held in buffaloes.

\section{KEYWORDS}

\author{
Buffaloes; MSCs; Coxal Tuberosity; Culture
}

\section{INTRODUCTION}

The ability of mesenchymal stem cells (MSCs) to differentiate into other mesoderm lineages such as bone and cartilage opened a variety of experimental strategies to investigate the possibility of these cells to be used in tissue engineering since MSCs derived from bone marrow (BM) have been applied in the treatment of musculoskeletal disease in several species [1]. Besides the differentiation capacity, those cells have the capacity of self-regeneration, low immunogenicity, paracrine, anti-inflammatory, immunomodulatory and antiapoptotic effects which make these cells a great alternative to be used in regenerative therapies.

Bone marrow-derived mesenchymal stem cells (BMMSCs) are the most studied source of MSCs and because of this, they have received special attention and are best characterized [2]. Bone marrow harvesting on coxal tuberosity (CT) has already been described in other species such as horses [3,4], dog, cat [5], sheep [6], pig [7] and humans [8].

In buffaloes, there are reports of studies with embryonic stem cells [9], MSCs derived from adipose tissue [1] and from amniotic fluid [10]. Based on this, this work 
aims to evaluate an alternative site of harvest of bone marrow in the CT and the cultivation of mesenchymal stem cells. The results of this study can contribute to and aid in the harvest of buffalo MSCs and maximize their therapeutic use.

\section{MATERIALS AND METHODS}

\subsection{Animals}

Six healthy adult female buffaloes aged 8 - 14 years were selected and used. The experimental protocol (No. 160/2012- CEUA) was approved by the ethics and welfare committee of the Sao Paulo State University - Botucatu. All procedures were performed under the international guidelines for the care and use of experimental animals.

\subsection{BM Harvesting}

Buffalo BM harvesting was performed on selected animals properly contained in a stock. The anatomical site of right CT was properly identified by palpation and it was performed trichotomy of the region. After this, antisepsis was done with chlorhexidine and alcohol (Riohex, Rioquímica-Brazil) followed by local anesthetic block with $10 \mathrm{ml}$ of $2 \%$ lidocaine (Cristália, Brazil). Past ten minutes, a myelogram's needle (Lang ${ }^{\circledR}$ Brasil) was introduced approximately $2 \mathrm{~cm}$ for bone marrowharvesting at an angle of approximately 45 degrees relative to the animal in dorsoventral and craniocaudal direction (Figure 1). Once the needle was firmly fixed in the CT, the mandril was removed and proceeded BM aspiration (Figure 2) with a syringe of $20 \mathrm{ml}$ properly identified containing $1 \mathrm{ml}$ of heparin at $1000 \mathrm{IU} / \mathrm{ml}$ (Hemofol ${ }^{\circledR}$, Cristália, BRA) and $1 \mathrm{ml}$ of PBS phosphate-saline, $\mathrm{pH}=7.2$ (PBS $^{\circledR}$ 1x, LGC Biotechnology, BRA). After BM harvesting, each sample collected was manually homogenized, identified, cooled and referred to the laboratory for isolation, cultivation and characterization from mononuclear fraction obtained from Histopaque $^{\circledR}\left(1077\right.$-Sigma ${ }^{\circledR}$, USA) gradient in a laminar flux environment.

\subsection{Isolation, Culture and Differentiation of MSC}

After collection, the samples were filtered and centrifuged at $340 \mathrm{~g}$ for ten minutes. The supernatant was removed and culture medium composed by DMEM lowglucose (Invitrogen ${ }^{\circledR}$, USA) was added.

Mononuclear fraction (MF) was isolated in a Histopaque ${ }^{\circledR}$ (1077-Sigma ${ }^{\circledR}$, USA) gradient (Figure 3 ), trough 40 minutes centrifugation at $340 \mathrm{~g}$. The MF was washed twice and cultured in DMEM low glucose/F12 (1:1), supplemented with $10 \%$ fetal bovine serum,
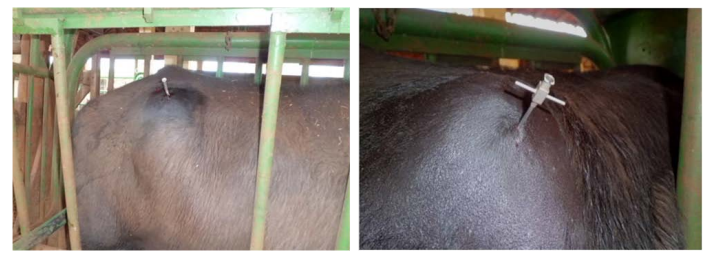

Figure 1. Myelogram's needle position for bone marrow harvesting on CT in buffaloes.

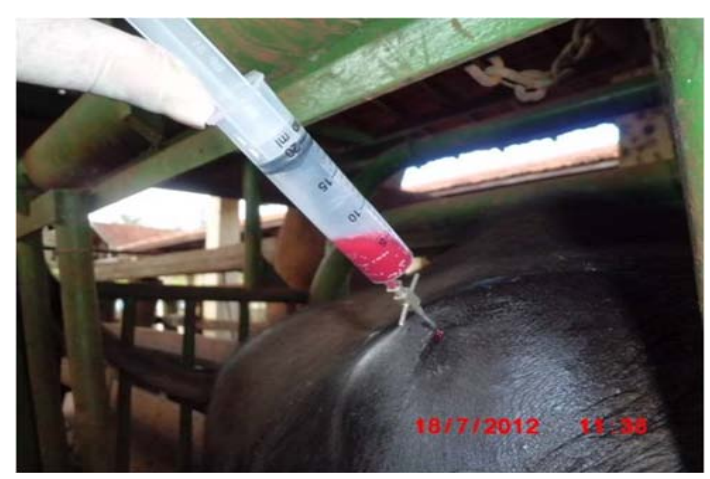

Figure 2. Bone marrow's harvest on CT with the use of a syringe of $20 \mathrm{ml}$.

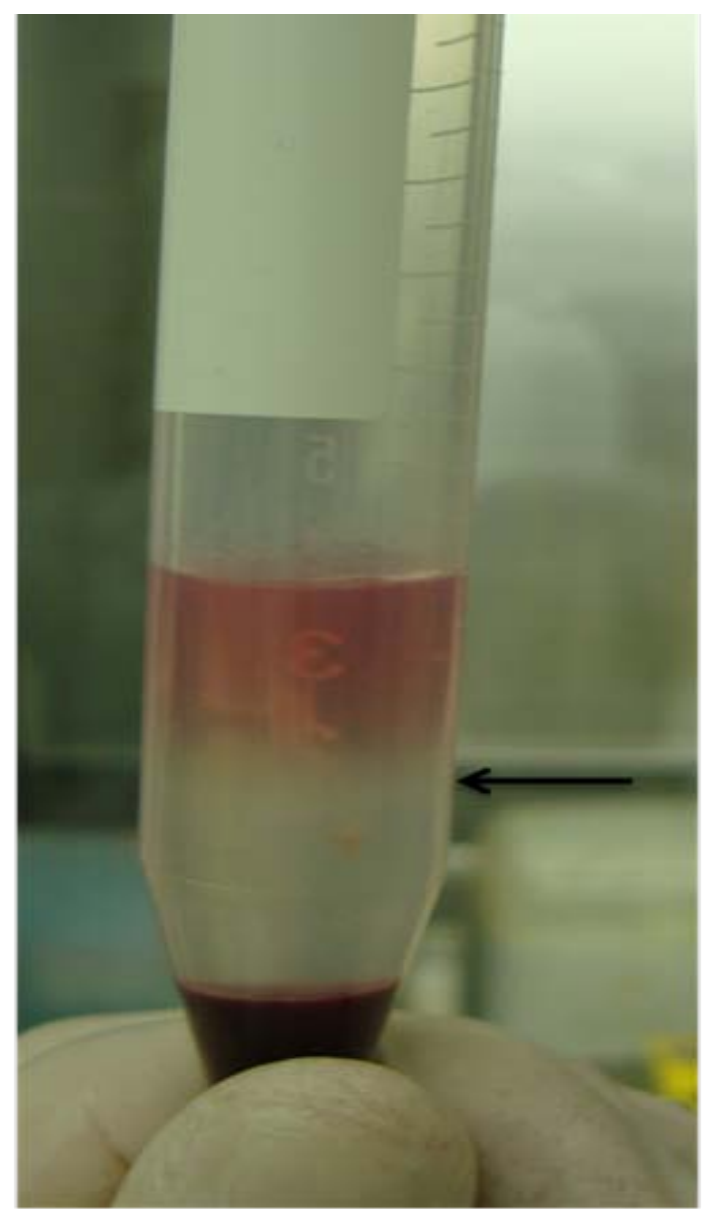

Figure 3. Mononuclear fraction formed after centrifugation on Histopaque ${ }^{\circledR}$ gradient. 
antibiotics (1\%) and antimycotics (1.2\%) (Invitrogen ${ }^{\circledR}$, USA) in humidified atmosphere containing $5 \% \mathrm{CO}_{2}$. Maintenance medium was changed at each two or three days and when the cells reached $80 \%$ confluence, first passage was performed by ressuspending the cells with TrypLE Express $^{\circledR}$ (Invitrogen $^{\circledR}$, USA, cat. number: 12604021), and transfer to 6-wells plates (Sarstedt $^{\circledR}$, USA) for differentiation assay into osteogenic and adipogenic lineage.

The differentiation protocol took about 10 days using media and supplements prepared from the Adipogenesis Differentiation Kit (Invitrogen ${ }^{\circledR}$, USA, cat. number: A10070-01) and the STEMPRO ${ }^{\circledR}$ Chondrogenesis media and supplements prepared from the Adipogenesis.

Differentiation Kit (Invitrogen ${ }^{\circledR}$, USA, cat. number: A10070-01) and the STEMPRO ${ }^{\circledR}$ Chondrogenesis Differentiation Kit (Invitrogen ${ }^{\circledR}$, USA, cat. number: A10071-01) according to manufacturer's recommendation. The medium of differentiation was changed every two days. At the end of differentiation period the morphological changes of cells were analyzed and samples were stained with $2 \%$ Alizarin Red (Sigma ${ }^{\circledR}$, USA, $\mathrm{pH}=$ 4.2) and $0,5 \%$ Oil Red (Sigma ${ }^{\circledR}$, US), for the observation of the deposit of calcium in the extracellular matrix and the presence of intracytoplasmic lipids droplets, respectively.

\section{RESULTS}

BM harvesting on CT was easily conduced and it was not found any difficult or problem during or after the collection. Furthermore, the needle, anesthetic protocol, doses and MSCs processing was considerate appropriate for the species under study.

From each animal it was collected on average $3 \mathrm{ml}$ of $\mathrm{BM}$ and this volume was sufficient for the processing of the sample from these animals, promoting correct isolation, culture and characterization of the cells. In one animal, with advanced age, the volume collected was lower $(1 \mathrm{ml})$ and the culture failed. The process of cooling the material during transport apparently did not affected the quality of the samples once all samples were submitted to culture.

The adhesion time for these cells was four days and the period between the adhesion and $80 \%$ confluence was on average 32 days (Figure 4). Morphological changes in cells in culture were observed during the differentiations period (Figure 5). Of all samples collected, the culture of only one animal (the older) failed. So of the five samples, four ( $80 \%$ ) were able to differentiate in osteogenic lineage and two (40\%) were able to differentiate in the adipogenic lineage. All samples showed morphological changes, but some presented no production of extracellular deposits of calcium or intracellular

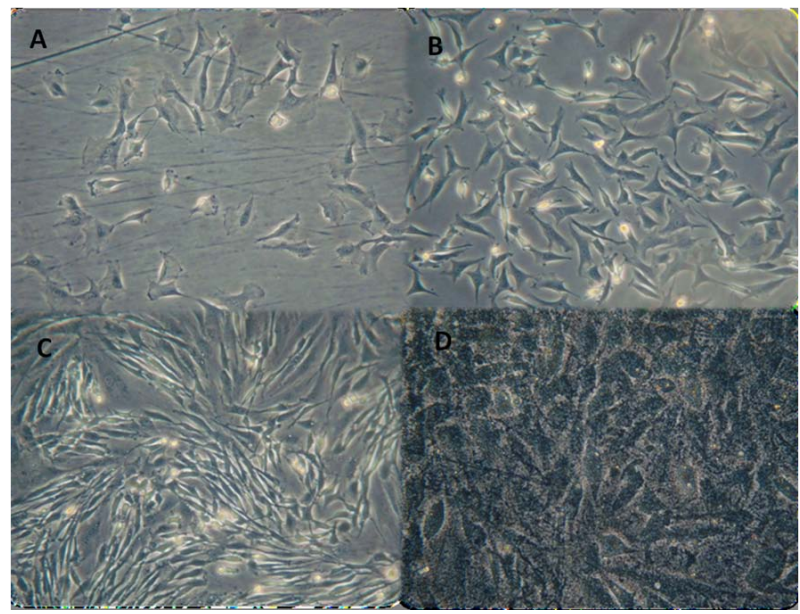

Figure 4. Buffalo MSCs during culture. A: beginning of cell adhesion-4 days; B: cell culture after 10 days; C: cell culture after 25 days. D: cell culture after 50 days. $20 \times$ magnification.

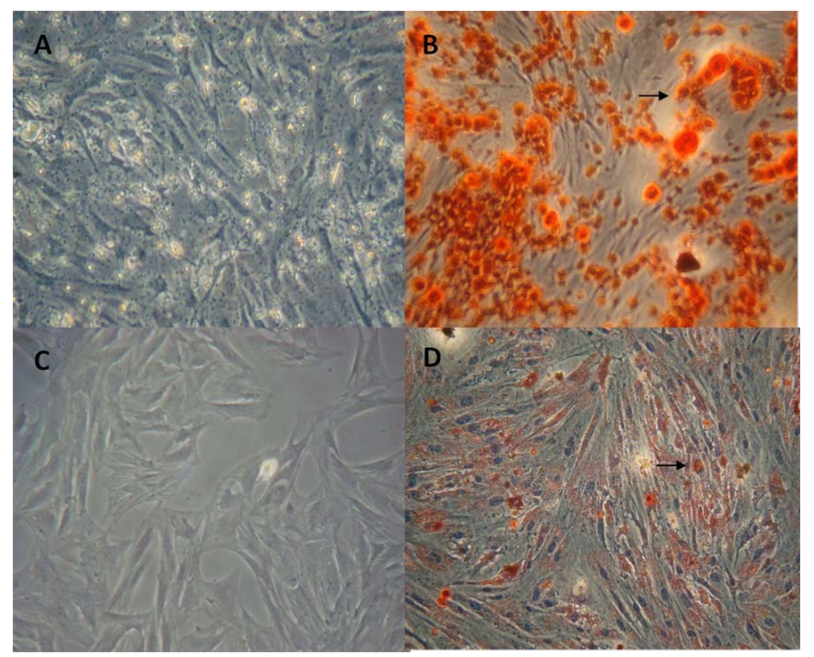

Figure 5. Differentiation assay for osteogenic and adipogenic lineages. A: beginning of osteogenic differentiation; B: red drops represented the extracellular deposit of calcium stained with Alizarin Red; C: beginning of adipogenic differentiation; D: intracellular lipid droplets stained with Oil Red. 20× magnification.

fat droplets, observed by staining with Alizarin Red and Oil Red, respectively.

\section{DISCUSSION}

The collection of BM in the CT of buffalo is considered safe both for the veterinarian and for the animal. Once held the correct contention, fact was also reported in horses [3].

Despite the possibility of obtaining MSCs from other sources such as adipose tissue [1], umbilical cord blood [8], peripheral blood [11], amniotic fluid [10], BM is considered the one that has the most abundant source of MSCs [8]. 
For BM harvesting in the CT of buffaloes, there is no need for general anesthesia, once a simple anesthetic block already allows the development of the technique. Such a fact makes the technique advantageous since adverse effects have been reported in human patients undergoing general anesthesia such as pain at the site of collection or even anemia [11]. Besides, this harvest can be done with the live animal, so there is no need to make a surgical wound. And the cells can be used in the same animal.

In this experiment, the volume collected from all animals was considerate properly. However, in other species, the volume collected was greater with data of $60 \mathrm{ml}$ in pigs [12], $10 \mathrm{ml}$ in humans [8], $11 \mathrm{ml}$ in horses [3] or 1 $\mathrm{ml}$ in dogs [13]. As already reported, the best sample for isolation and expansion of MSCs is obtained in the early stages of bone marrow aspiration. Furthermore, it is known that the volume of material obtained decreases along the samples [8].

In one animal from this study, it was observed that the volume material collected was lower $(1 \mathrm{ml})$ and yellowish. This can be explained by the advanced age of this animal in order that the hematopoietic tissue is gradually replaced by non-hematopoietic mesenchymal cells, also called fatty bone marrow [14].

Compared with samples from other species processed in the same laboratory, a longer primary culture time was observed during culture. For example, in dogs the time to reach confluence is on average 10 days (unpublished data) and in horses is on average 22 days [15].

With respect to differentiation, heterogeneity in response to differentiation after induction was noted. Perhaps this response is linked with an inadequacy of the differentiation media used. However, it is important to remember that intrinsic difference among the samples cannot be ruled out. Since the population of mesenchymal stem cells contained in bone marrow environment is heterogeneous, it is committed to diverse differentiation processes.

With this protocol proposed, it was evident that the antisepsis, local block and site of harvest were efficient on buffaloes and can be used in this species for bone marrow harvesting from CT. The anatomical site tested showed to be an alternative site of harvest of BM once provided with appropriate isolation, culture and characterization of mononuclear fraction. Besides, the procedure was performed without difficulty and with great security. Although the osteogenic potential was evident, the adipogenic differentiation needs to be improved. Based on the above, it can be concluded that CT is an excellent anatomical site for isolation and culture of MSCs and that the proposed technique is viable and feasible to be held in buffaloes and can be used in future researches.

\section{ACKNOWLEDGEMENTS}

The authors ensure that there are no conflicts of interest (including specific financial interest and relationships and affiliation).

\section{REFERENCES}

[1] Hepsibha, P., Meenambigai, T.V., Mangalagowri, A., Palanisamy, A., Stalin, A., Nithya, S. and Humanan, K. (2011) Multipotent differentiation potential of buffalo adipose tissue derived mesenchymal stem cells. Asian Journal of Animal and Veterinary Advances, 6, 772-788. http://dx.doi.org/10.3923/ajava.2011.772.788

[2] Fortier, L.A. and Travis, A.J. (2011) Stem cells in veterinary medicine. Stem Cell Research, 2, 1-6. http://dx.doi.org/10.1186/scrt50

[3] Delling, U., Lindner, K., Ribitsch, I., Jülke, H. and Brehm, W. (2012) Comparison of the bone marrow aspiration at the sternum and the tuber coxae in middle-aged horses. Canadian Journal of Veterinary Research, 76, 52-56.

[4] Maia, L., Venturini, R.M., Taffarel, M.O., Freitas, N.P.P., Monteiro, G.A., de Vita, B., Monteiro, B.A., LandimAlvarenga, F.C. and Amorim, R.M. (2011) Técnica de colheita da medula óssea na tuberosidade coxal de eqüinos para isolamento e cultivo de células tronco mesenquimais. Procedings of XII Conferência Anual da ABRAVEQ, Campinas, 117.

[5] Townsend, F.I. (2008) Bone marrow aspiration in dogs and cats. Laboratory Animals, 37, 497-498. http://dx.doi.org/10.1038/laban1108-497.

[6] Amorim, R.M., Nascimento, G.D., Maia, L., Listoni, A.J., Paola, B.S., Ferreira, D.L.O., Cavalcanti, R.M. and LandimAlvarenga, F.C. (2012) Bone marrow mesenchymal stem cells from sheep. Proceedings of the XXVII World Buiatrics Congress, Lisbon, 3 June 2012, 323.

[7] Abukawa, H., Phelps, M., Jackson, P., Smith, R.M., Vacanti, J.P., Kaban, L.B. and Troulis, M.J. (2009) Effect of ibuprofen on osteoblast differentiation of porcine bone marrow-derived progenitor cells. Journal of Oral and Maxillofacial Surgery, 67, 2412-2417. http://dx.doi.org/10.1016/j.joms.2009.05.434

[8] Li, J., Wong, W.H.S., Chan, S., Chim, J.C.S., Cheung, K.M.C., Lee, T.L., Au, W.Y., Ha, S.Y., Lie, A.K.W., Lau, Y.L., Liang, R.H.S. and Chan G.C.F. (2011) Factors affecting mesenchymal stromal cells yield from bone marrow aspiration. Chinese Journal of Cancer Research, 23, 43-48. http://dx.doi.org/10.1007/s11670-011-0043-1

[9] Verma, V., Gautam, S.K., Singh, B., Manik, R.S., Palta, P., Single, S.K., Goswami, S.L. and Chauhan, M.S. (2007) Isolation and characterization of embryonic stem cell-like cells from in vitro-produced buffalo (Bubalus bubalis) embryos. Molecular Reproduction and Development, 74, 520-529. http://dx.doi.org/10.1002/mrd.20645

[10] Dev, K., Gautam, S.K., Giri, S.K., Kumar, A., Yadav, A., Verma, V., Kumar, P. and Singh, B. (2012) Isolation, culturing and characterization of feeder-independent amniotic fluid stem cells in buffalo (Bubalus bubalis). Research of Veterinary Science, 93, 743-748. http://dx.doi.org/10.1016/j.rvsc.2011.09.007 
[11] Styczynski, J., Balduzzi, A., Gil, L., Labopin, M., Hamladji, R.M., Marktel, S., Yesilipek, M.A., Fagioli, F., Ehlert, K., Matulova, M., Dalle, J.H., Wachowiak, J., Miano, M., Messina, C., Diaz, M.A., Vermylen, C., Eyrich, M., Badell, I., Dreger, P., Gozdzik, J., Hutt, D., Rascon, J., Dini, G. and Peters, C. (2012) Risk of complications during hematopoietic stem cell collection in pediatric sibling donors: A prospective European group for blood and marrow transplantation pediatric diseases working party study. Blood, 19, 2935-2941. http://dx.doi.org/10.1182/blood-2011-04-349688

[12] Branco, E., Cabral, R., Gomes, B.D., Kfoury Jr., J.R. and Miglino, M.A. (2012) Bone marrow cells of swine: Collection and separation. Microscopy Research and Technique, 7, 5917-920. http://dx.doi.org/10.1002/jemt.22013

[13] Defarges, A., Abrams-Ogg, A., Foster, R.A. and Bienzle,
D. (2013) Comparision of sterna, iliac, and humeral bone marrow aspiration in Beagle dogs. Veterinary Clinical Pathology, 42, 170-176. http://dx.doi.org/10.1111/vcp.12036

[14] Gurevitch, O., Slavin, S. and Feldman, A.G. (2007) Conversion of red bone marrow into yellow-Cause and mechanisms. Medical Hypotheses, 69, 531-536. http://dx.doi.org/10.1016/j.mehy.2007.01.052

[15] Maia, L., Landim-Alvarenga, F.C., Mota, L.S.L.S., Golim, M.A., Laufer-Amorim. R., de Vita, B., Barberini, D.J., Listoni, A.J., Moraes, C.N., Heckler, M.C.T. and Amorim, R.M. (2013) Immunophenotypic, immunocytochemistry, ultrastructural, and cytogenetic characterization of mesenchymal stem cells from equine bone marrow. Microscopy Research and Technique, 76, 618-624. http://dx.doi.org/10.1002/jemt.22208 